DOI: https://doi.org/10.24127/ajpm.v10i3.3874

\title{
ANALISIS KEMAMPUAN PEMECAHAN MASALAH PADA SOAL BERBASIS HIGH ORDER THINKING DITINJAU DARI KEMAMPUAN SPASIAL
}

\author{
Mahfuddin $^{1}$, Caswita ${ }^{2 *}$ \\ $1,2^{*}$ Universitas Lampung, Bandar Lampung, Indonesia \\ *Corresponding author. Lampung 35229, Bandar Lampung, Indonesia. \\ E-mail: $\quad \frac{\text { mahfuddin1009@gmail.com }}{\text { wcaswita@yahoo.com }}^{2^{* 1}}$
}

Received 28 June 2021; Received in revised form 12 September 2021; Accepted 27 September 2021

\begin{abstract}
Abstrak
Kemampuan pemecahan masalah matematis memiliki peran yang sangat penting. Namun, masih banyak siswa yang memiliki kemampuan pemecahan masalah yang rendah. Tujuan dari penelitian yaitu untuk mendeskripsikan kemampuan pemecahan masalah siswa dalam menyelesaikan soal geometri transformasi berbasis high order thinking ditinjau dari kemampuan spasial. Penelitian ini termasuk penelitian kualitatif dengan metode studi kasus. Hasil penelitian ini menunjukkan siswa dengan kemampuan spasial tinggi mampu melalui tahapan pemecahan masalah dengan level kognitif menganalisis, mengevaluasi, dan mencipta. Siswa dengan kemampuan spasial sedang mampu melalui tahapan pemecahan masalah dengan level kognitif menganalisis dan mengevaluasi. Pada level kognitif mencipta, siswa dengan kemampuan spasial sedang hanya mampu memahami masalah dan merencanakan penyelesaian. Siswa dengan kemampuan sedang belum mampu melaksanakan penyelesaian dengan baik dan menemukan gagasannya dalam memecahkan permasalahan. Siswa dengan kemampuan spasial rendah hanya mencapai tahap level kognitif menganalisis, pada level kognitif mengevaluasi, siswa ini hanya mampu memahami permasalahan tanpa memberikan penyelesaian, sedangkan pada level kognitif mencipta, siswa ini tidak memahami masalah yang diberikan. Hal ini menunjukkan kemampuan spasial tinggi lebih baik dalam menyelesaikan soal geometri transformasi berbasis high order thinking.
\end{abstract}

Kata kunci: Geometri transformasi; high order thinking; kemampuan spasial.

\begin{abstract}
Mathematical problem solving ability has a important role. However, there are many students who have low problem solving abilities. The purpose of this research is to describe students' problem solving abilities in solving geometric transformation problems based on high order thinking in terms of spatial abilities. This research is qualitative research with case study method. The results of this study indicate that students with high spatial abilities are able to go through the stages of problem solving with cognitive levels of analyzing, evaluating, and creating. Students with moderate spatial ability are able to go through the stages of problem solving with the cognitive level of analyzing and evaluating. At the cognitive level of creation, these students are only able to understand problems and plan solutions. Students with moderate abilities haven't been able to carry out solutions and find ideas. Students with low spatial abilities only reach the analyzing stage, at the cognitive level of evaluating, these students are only able to understand the problem without providing solution, while at the cognitive level of creating, these students don't understand the given problem. This shows that high spatial ability is better in solving transformation geometry problems based on high order thinking.
\end{abstract}

Keywords: High order thinking; spatial ability; transformation geometry. 
DOI: https://doi.org/10.24127/ajpm.v10i3.3874

\section{PENDAHULUAN}

Matematika merupakan bagian penting dari pendidikan nasional dan merupakan salah satu ilmu universal yang mendasari perkembangan teknologi modern. Dalam pembelajaran matematika salah satu kemampuan dasar yang harus dimiliki oleh siswa adalah kemampuan pemecahan masalah. Pemecahan masalah merupakan konsep yang paling efektif untuk kontekstualitas dan rekontekstualitas konsep, untuk operasional dan transfer dasar pengetahuan matematika, dan untuk memastikan pembelajaran yang berkelanjutan serta bermakna (Capriora, 2015). Oleh karena itu, kemampuan pemecahan masalah matematis memiliki peranan yang sangat penting dalam tercapainya tujuan pendidikan matematika di sekolah karena akan menjadi bekal bagi siswa, bukan hanya di sekolah pada saat pembelajaran namun juga untuk menghadapi kehidupan di masyarakat (Azizah, 2015; Nurhayati et al., 2016)

Ilmu matematika dibangun dari konsep-konsep dasar dan kemudian dikembangkan ke konsep yang lebih rumit, yang dalam pengerjaannya diperlukan ketrampilan berpikir tingkat tinggi atau lebih dikenal dengan istilah HOTS (High Order Thinking Skill s). HOTS terbagi dalam beberapa tingkatan kemampuan yang merujuk pada Taksonomi Bloom. Gagasan ini membagi ketrampilan berpikir menjadi 6 bagian, yaitu mengingat (C1), memahami (C2), dan mengaplikasikan sesuatu rumus atau hukum (C3) yang masuk dalam kriteria keterampilan berpikir tingkat rendah (Low Order Thinking Skills - LOTS), sedangkan keterampilan berikir analisis (C4), evaluasi (C5) dan mengkreasi (C6) termasuk dalam kategori keterampilan berpikir tingkat tinggi (High Order
Thinking Skill - HOTS) (Mahmudiati \& Alawiyah, 2018)

Berdasarkan hasil analisis oleh Programme for International Student Assessment (PISA) dan (Trend in International Mathematics and Science) TIMSS, menyatakan bahwa kemampuan siswa Indonesia dalam menyelesaikan masalah non rutin masih rendah, walaupun siswa Indonesia lebih bagus dalam hal menyelesaikan soalsoal berupa fakta dan prosedural (Putra \& Novita, 2014). Hal ini menunjukan bahwa kemampuan pemecahan masalah siwa Indonesia masih tergolong rendah.

Pada dasarnya setiap manusia diciptakan berbeda beda dalam menyelesaikan masalah, salah satunya karena faktor perbedaan kemampuan spasial yang dimiliki oleh siswa. Kemampuan spasial merupakan kemampuan mempersepsi dunia visual dengan akurat, mentranformasi dan memodifikasi pengalaman visual seseorang, bahkan ketika tidak ada rangsangan fisikal yang relevan. Kemampuan spasial terbagi menjadi tiga yaitu kemampuan spasial rendah, sedang dan tinggi (Hodiyanto, 2018) Kemampuan spasial yang dimaksud adalah kemampuan seseorang dalam memahami suatu objek dengan memvisualisasikannya, artinya mengimajinasikan objek yang ingin dipahami ke dalam dua atau tiga dimensi.

Berdasarkan hasil ulasan di atas, penting untuk menganalisis kemampuan pemecahan masalah siswa dalam menyelesaikan soal HOTS ditinjau dari kemampuan spasial. Beberapa penelitian terdahulu telah melakukan penelitian dalam menganalisis kemampuan pemecahan masalah siswa (Agoestanto et al., 2013; Azizah, 2015; Gunur et al., 2018; Imamah \& Toheri, 2014; Komala, 2012; Kusumawati, 2014; Mita et al., 2019; Ngaeni \& 
Saefudin, 2017; Ramadhani, 2017; Simanjuntak et al., 2019; Yurniati \& Wahyuningrum, 2015) kemampuan siswa dalam menyelesaikan soal HOTS serta penelitian yang meninjau dari kemampuan spasial.(Fajri et al., 2016; Gurun et al., 2018; Hodiyanto, 2018; Kusuma, 2017; Negara, H. R., Atmojo, T., \& Sujadi, 2014; Rikanah \& Winarso, 2016; Suroyya \& Rochmad, 2015; Syahputra, 2013) Namun belum terdapat penelitian yang menganalisis kemampuan pemecahan masalah ditinjau dari kemampuan spasial, padahal melihat kemampuan seseorang ditinjau dari kemampuan spasial nya penting untuk diketahui. Oleh karena itu, penelitian ini bertujuan untuk menganalisis kemampuan pemecahan masalah siswa pada materi Geometri Transformasi yang ditinjau dari kemampuan spasial siswa kelas IX SMP Qur'an Nurul Huda di Kabupaten Pesawaran.

\section{METODE PENELITIAN}

Penelitian ini ditinjau dari jenisnya termasuk penelitian deskriptif kualitatif dengan metode studi kasus. Penelitian ini bersifat alami dan menampilkan keadaan sebagaimana adanya, tanpa ada unsur manipulasi atau perlakuan khusus terhadap objek penelitian. Adapun tahapan yang dilakukan dalam penelitian ini, yaitu tahap persiapan, tahap pelaksanaan, dan tahap akhir. Pada tahap persiapan, peneliti menyiapkan segala hal yang berhubungan dengan penelitian, seperti surat izin penelitian, lembar observasi, lembar wawancara, lembar tes kemampuan spasial, dan instrumen high order thinking. Pada tahap pelaksanaan, peneliti memberikan tes kemampuan spasial pada siswa. Hal ini dilakukan untuk mengelompokkan siswa berdasarkan tingkat kemampuan spasialnya. Selain itu, pada tahap ini juga diberikan tes kemampuan pemecahan masalah berbasis HOTS yang kemudian akan diamati bagaimana proses siswa dalam pemecahan masalah. Pada tahap akhir, data yang diperoleh pada tahap pelaksanaan diolah dan dianalisis baik secara kuantitatif maupun secara kualitatif.

Penelitian ini dilaksanakan di SMP Qur'an Nurul Huda pada semester genap tahun ajaran 2020/2021. Teknik pengambilan sampel dalam penelitian ini menggunakan purposive sampling. Purposive sampling adalah teknik penentuan sampel dengan pertimbangan tertentu, pengambilan sampel disesuaikan dengan kebutuhan dan tujuan penelitian. Kriteria yang dijadikan pertimbangan pengambilan sampel, yaitu siswa dengan kemampuan spasial tinggi, sedang, dan rendah. Sampel dalam penelitian ini berjumlah 3 orang siswa, yaitu 1 siswa berkemampuan spasial tinggi, 1 siswa berkemampuan spasial sedang, dan 1 siswa dengan kemampuan spasial rendah.

Instrumen dalam penelitian, yaitu instrumen tes kemampuan spasial, instrumen tes kemampuan pemecahan masalah yang berbasis HOTS, dan pedoman wawancara. Sebelum dilakukan tes, instrumen tersebut diuji validitas isinya oleh validator ahli sehingga instrumen lebih dapat dipercaya dalam mengukur. Adapun kriteria penilaian tes kemampuan spasial berdasarkan skor yang diperoleh dapat dilihat pada Tabel 1 .

Tabel 1. Kriteria penilaian tes kemampuan spasial

\begin{tabular}{ccc}
\hline No & Rentang Skor & Kriteria \\
\hline 1 & $75 \leq$ skor $\leq 100$ & Spasial tinggi \\
2 & $60 \leq$ skor $<75$ & Spasial sedang \\
3 & $0 \leq$ skor $<60$ & Spasial rendah \\
\hline
\end{tabular}


DOI: https://doi.org/10.24127/ajpm.v10i3.3874

Analisis data penelitian ini menggunakan dua teknik, yaitu analisis pemecahan masalah yang berorientasi HOTS dan analisis wawancara. Analisis tes kemampuan pemecahan masalah dilakukan untuk melihat siswa dalam menyelesaikan soal geometri berbasis HOTS yang disesuaikan dengan indikator pemecahan masalah. Sedangkan teknik analisis data wawancara dengan tahap (1) reduksi data; (2) penyajian data; dan (3) penarikan simpulan.

\section{HASIL DAN PEMBAHASAN}

Data yang diperoleh dalam penelitian ini merupakan data kualitatif dengan menggunakan instrumen tes kemampuan spasial, instrumen tes kemampuan pemecahan masalah berbasis high order thinking, dan pedoman wawancara. Langkah awal yang peneliti lakukan yaitu menguji cobakan instrumen tes kemampuan spasial untuk melihat tingkat kemampuan spasial siswa yang dikategorikan sebagai siswa dengan kemampuan spasial rendah, sedang, dan tinggi. Peneliti mengambil sampel sebanyak 3 orang dengan kemampuan spasial yang berbeda-beda. Hasil pengujian tes kemampuan spasial disajikan pada Tabel 2.

Tabel 2. Hasil perolehan tes kemampuan spasial

\begin{tabular}{ccc}
\hline Subjek & Skor & Kriteria \\
\hline UVK & 82,35 & Spasial tinggi \\
DAP & 64,70 & Spasial sedang \\
RFB & 52,94 & Spasial rendah \\
\hline
\end{tabular}

Selanjutnya, data hasil tes kemampuan spasial pada Tabel 2 dijadikan sebagai rujukan peneliti untuk mengindentifikasi tahapan pemecahan masalah siswa dengan menggunakan instrumen soal berbasis HOT dengan indikator menganalisis (C4), mengevaluasi (C5), dan Mencipta (C6). Agar butir soal dapat menuntun siswa untuk berpikir tingkat tinggi, maka setiap butir soal selalu diberikan dasar pertanyaan (stimulus) yang berbentuk sumber/bahan bacaan sebagai informasi seperti: teks bacaan, paragraf, teks drama, penggalan novel/cerita/dongeng, puisi, kasus, gambar, grafik, foto, rumus, tabel, daftar kata/simbol, contoh, peta, film, atau rekaman suara.(Lailly \& Wisudawati, 2015). Data hasil penelitian disajikan sebagai berikut:

\section{Siswa dengan Kemampuan Spasial Tinggi}

Subjek UVK memperoleh skor 82,35 pada tes kemampuan spasial, sehingga subjek UVK dikategorikan sebagai siswa dengan kemampuan spasial tinggi. Berikut penjelasan dari tahapan pemecahan masalah subjek UVK.

\section{a. Soal level kognitif menganalisis (C4)}

Pada soal level kognitif analisis, siswa dikatakan memiliki kemampuan menganalisis jika siswa mampu memeriksa kebenaran argumen, membuat blueprint, memecahkan permasalahan, mengkarakteristikan, menghubungkan, mendiagnosis, menyeleksi, memerinci, dan menguji. Hasil tes subjek UVK pada soal dengan level kognitif menganalisis dijelaskan pada Gambar 1.

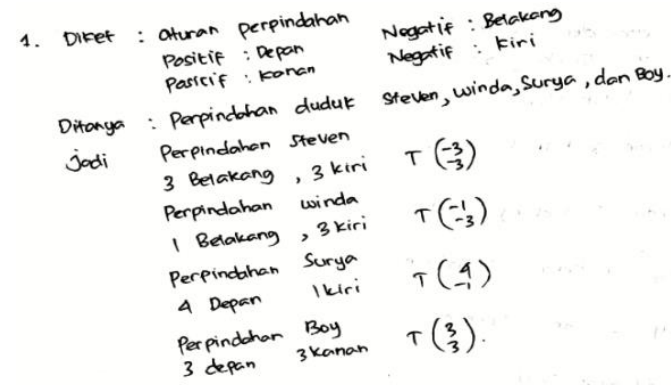

Gambar 1. Jawaban UVK dalam memecahkan soal level kognitif menganalisis 
DOI: https://doi.org/10.24127/ajpm.v10i3.3874

Adapun tahapan pemecahan masalah yang dilakukan subjek UVK yaitu, (1) Memahami masalah, pada tahap ini UVK mampu memahami permasalahan yang diberikan. UVK mampu menjelaskan kembali informasi yang diberikan soal baik secara tertulis, maupun secara lisan serta mampu mengaitkan masalah tersebut dengan konsep geometri transformasi, sehingga UVK memenuhi indikator memahami masalah; (2) Merencanakan penyelesaian, pada tahap ini UVK mampu menghubungkan permasalahan dalam soal dan memilih strategi yang tepat dalam menyelesaikan soal. UVK mampu menjelaskan strategi yang harus dilakukan dalam menyelesaikan masalah tersebut secara lisan dan tertulis. Sehingga UVK memenuhi indikator merencanakan Penyelesaian; (3) Melaksanakan penyelesaian, Pada tahap ini siswa UVK mampu melaksanakan strategi yang dipilihnya dengan baik. UVK mampu menyelesaikan permasalahan pada level kognitif menganalisis, sehingga UVK memenuhi indikator melaksanakan penyelesaian masalah; (4) Memeriksa kembali, Pada tahap ini UVK memeriksa kembali proses jawaban yang dilakukan. UVK juga mampu memberikan kesimpulan dari proses yang dilakukan, subjek UVK yakin terhadap penyelesaian yang telah dilakukan, sehingga UVK memenuhi indikator memeriksa kembali.

\section{b. Soal Level Kognitif Evaluasi (C5)}

Pada soal level kognitif evaluasi, siswa dikatakan memiliki kemampuan mengevaluasi jika siswa mampu menilai suatu argumen, mempertimbangkan, membandingkan, mengkritik suatu pernyataan, menafsirkan, dan memutuskan. Adapun hasil tes subjek UVK pada soal level kognitif mengevaluasi dapat dijelaskan pada Gambar 2.

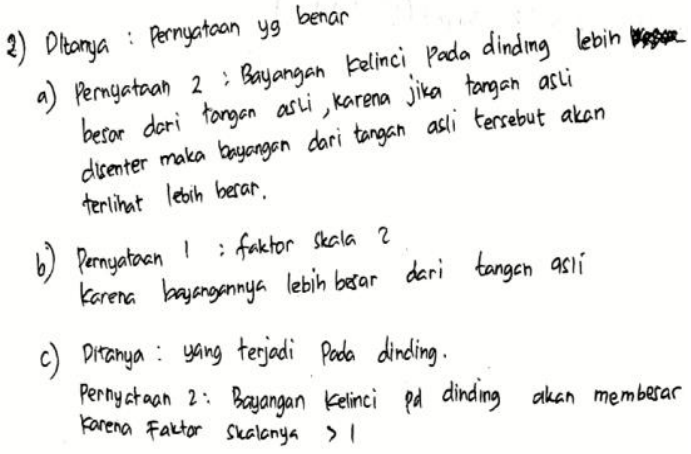

Gambar 2. Jawaban UVK dalam memecahkan soal level kognitif mengevaluasi

Tahapan pemecahan masalah yang dilakukan oleh subjek UVK yaitu, (1) Memahami masalah, pada tahap ini UVK tidak menuliskan informasi yang diberikan dalam soal secara tertulis, namun subjek ini memahami permasalahan yang diberikan. Subjek UVK mampu menjelaskan apa yang menjadi permasalahan dalam soal secara verbal; (2) Merencanakan penyelesaian, pada tahap ini UVK menuliskan rencana yang akan dilakukan untuk menyelesaikan soal dan memilih strategi yang tepat dalam menyelesaikan soal yaitu dengan membayangkan sebuah objek yang disorot dengan lampu senter, sehingga UVK memenuhi indikator merencana-kan penyelesaian; (3) Melaksanakan penyelesaian, pada tahap ini UVK mampu menjalankan rencana yang telah dipilihnya dan mampu memutuskan pernyataan benar serta mampu memberikan alasan dengan bahasanya sendiri, sehingga UVK memenuhi indikator melaksanakan penyelesaian; (4) Memeriksa kembali, pada tahap ini UVK tidak memberikan kesimpulan terhadap hasil yang diperolehnya, namun subjek UVK yakin terhadap jawaban yang diberikan. 


\section{c. Soal Level Kognitif Mencipta (C6)}

Pada soal level kognitif mencipta, siswa dikatakan mencapai level kognitif mencipta jika siswa mampu mengabstraksi objek, mengkategorikan, mengkombinasikan, menyusun, menciptakan gagasan, mengkreasikan, merancang, dan mengembangkan. Data hasil tes soal dengan level kognitif mencipta dapat dilihat pada Gambar 3.

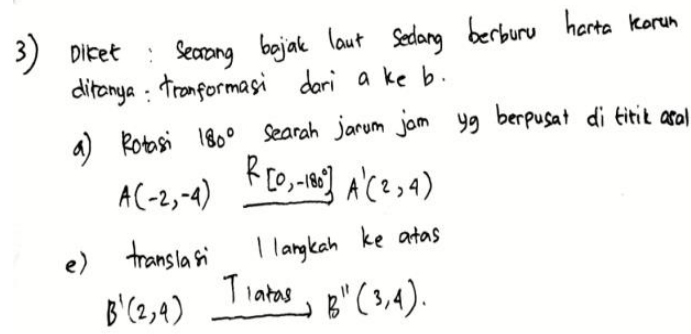

Gambar 3. Jawaban UVK dalam memecahkan soal level kognitif mencipta

Adapun tahapan pemecahan masalah subjek UVK yaitu, (1) Memahami masalah, pada tahap ini UVK mampu memahami permasalahan yang ada pada soal. UVK mampu menuliskan informasi dalam soal dengan bahasanya sendiri dan mampu menjelaskan secara lisan masalah yang diberikan, sehingga UVK memenuhi indikator memahami masalah; (2) Merencanakan penyelesaian, pada tahap ini UVK memahami strategi yang tepat dalam menyelesaikan soal, menjelaskan secara lisan rencana yang harus dilakukan dan menuliskan rencana yang harus dilakukan pada lembar soal, subjek UVK menjelaskan secara baik langkah apa yang harus dilakukan untuk menyelesaikan soal, sehingga UVK memenuhi indikator merencanakan penyelesaian; (3) Melaksanakan penyelesaian, pada tahap ini UVK mampu melaksanakan strategi yang telah dipilihnya dengan baik. UVK mampu menyelesaikan permasalahan pada level kognitif mencipta, UVK mampu mengembangkan ide atau gagasannya dalam menyelesaikan soal level kognitif mencipta, sehingga UVK memenuhi indikator melaksanakan penyelesaian masalah; (4) Memeriksa kembali, pada tahap ini UVK yakin terhadap gagasannya dalam menyelesaikan soal dengan level kognitif mencipta, UVK juga melakukan pengecekan terhadap gagasannya, namun UVK tidak memberikan kesimpulan dari hasil yang diperolehnya.

Berikut cuplikan wawancara dengan siswa dengan kemampuan spasial tinggi.

$R$ : Apakah kamu mengerti permasalahan apa yang ada pada soal no 1,2, dan 3 ?

UVK : Iya paham pak

$R \quad$ : Bagaimana kamu memahami nya?

UVK : Untuk soal no 1, kita disuruh mencari perpindahan tempat duduk lalu bentuk translasinya, kalo soal no 2 kita diminta untuk memilih pernyataan yang bener, kalo soal no 3 kita disuruh mencari langkah transformasi supaya harta karunnya bisa ditemuin sama bajak laut

$R$ : Lalu bagaimana caramu menyelesaikannya?

UVK : Untuk soal no 1, saya mengikuti aturan pak, berapa perpindahan kanan,kiri, atas, dan bawah. Kalo no 2 itu memilih soal sesuai dengan konsep dilatasi. Kalo no 3 kita tinggal memilih dari pilihan yang ada untuk bantu bajak laut dapetin harta karun pak.

$R \quad:$ Apakah kamu sudah yakin dengan jawbannya? 
DOI: https://doi.org/10.24127/ajpm.v10i3.3874

\section{Bagaimana cara kamu mengecek jawaban tersebut? \\ UVK : udh dicek pak, insyaa Allah yakin pak}

\section{Siswa dengan Kemampuan Spasial Sedang}

a. Soal Level Kognitif Menganalisis (C4)

$$
\begin{aligned}
& \text { 1h Diket : Pindah ke karon atau depan } \Rightarrow \text { Positif } \\
& \text { Pindah Ke kiri attau Belakang } \Rightarrow \text { negatif } \\
& \text { Dranga : Perpindohan Posisi duduk Steven, winda, Surya } \\
& \text { jawab } \Rightarrow \text { Perpindahon steven } 3 \text { kebelakong, } 3 \text { kekiri } \\
& T\left(\begin{array}{l}
-3 \\
-3
\end{array}\right) \\
& \text { Perpindahan winda } 2 \text { belakang, } 3 \text { kekiri } \\
& \begin{array}{c}
T\left(\begin{array}{c}
-2 \\
-3
\end{array}\right) \\
\text { Perpindathor surya } 1 \text { ketiri, } 3 \text { kedepan }
\end{array} \\
& T\left(\begin{array}{l}
-1 \\
3
\end{array}\right) \\
& \text { Perpindohan boy, } 2 \text { depen } 3 \text { kanan } \\
& T\left(\begin{array}{c}
2 \\
3
\end{array}\right) \\
& \text { jodi Boy duduk ditempat santi } \\
& \text { jabi Steven } T\left(\begin{array}{c}
-3 \\
-3
\end{array}\right) \text {, winda } T\left(\begin{array}{l}
-2 \\
-3
\end{array}\right) \text {, surya } T\left(\begin{array}{l}
3 \\
-1
\end{array}\right) \text {, Boy } T\left(\begin{array}{l}
2 \\
3
\end{array}\right)
\end{aligned}
$$

Gambar 4. Jawaban DAP dalam memecahkan soal level kognitif menganalisis

Berdasarkan Gambar 4, tahapan pemecahan masalah yang dilakukan subjek DAP yaitu, (1) Memahami masalah, pada tahap ini DAP mampu memahami permasalahan pada level kognitif mengevaluasi. DAP mampu menuliskan kembali permasalahan dengan bahasanya sendiri, sehingga DAP memenuhi indikator memahami masalah; (2) Merencanakan penyelesaian, pada tahap ini DAP mampu mendapatkan strategi yang tepat dalam menyelesaikan soal. DAP menuliskan rencana yang akan dilakukan dalam menyelesaikan soal dan mampu menjelaskan strategi yang dipilihnya, sehingga DAP memenuhi indikator merencanakan penyelesaian;

Melaksanakan penyelesaian, pada tahap ini siswa DAP melaksanakan strategi yang dipilihnya dengan baik. DAP mampu menyelesaikan permasa-lahan yang diberikan secara sistematis pada level kognitif menganalisis, sehingga DAP memenuhi indikator melaksanakan penyelesaian masalah; (4) Memeriksa kembali, pada tahap ini DAP yakin terhadap analisisnya, mampu memberikan kesimpulan dari masalah, sehingga DAP memenuhi indikator memeriksa kembali.

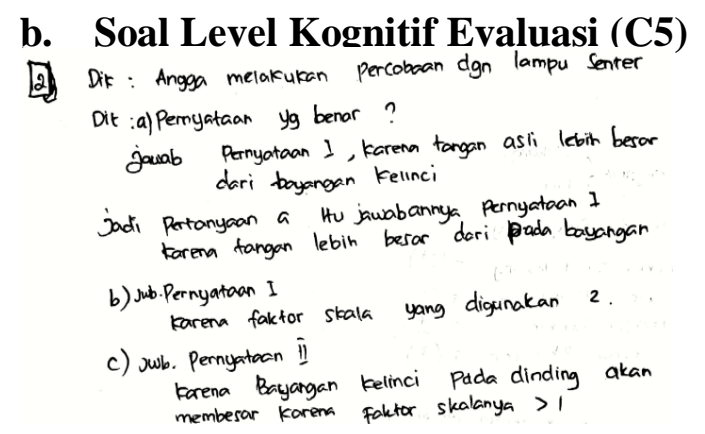

Gambar 5. Jawaban DAP dalam memecahkan soal level kognitif mengevaluasi

Berdasarkan Gambar 5, tahapan pemecahan masalah subjek DAP pada soal level kognitif mengevaluasi yaitu, (1) Memahami masalah, pada tahap ini DAP memahami masalah yang diberikan, DAP mampu menuliskan kembali informasi yang diperolehnya dalam lembar jawaban dengan bahasanya sendiri, sehingga DAP memenuhi indikator memahami masalah; (2) Merencanakan penyelesaian, pada tahap ini DAP mampu memberikan strategi yang tepat dalam menyelesaikan soal, sehingga DAP memenuhi indikator merencanakan penyelesaian; (3) Melaksanakan penyelesaian, pada tahap ini DAP mampu memberikan jawaban yang tepat, DAP mampu memberikan pertimbangan dari pernyataan yang diberikan dan mengambil keputusan yang tepat, sehingga DAP memenuhi indikator melaksanakan penyelesaian; (4) memeriksa kembali, pada tahap ini DPA melakukan pengecekan ulang terhadap jawaban yang telah diberikan, subjek 
DAP yakin terhadap jawaban yang telah diberikan, sehingga DAP memenuhi indikator memeriksa kembali.

\section{c. Soal Level Kognitif Mencipta (C6)

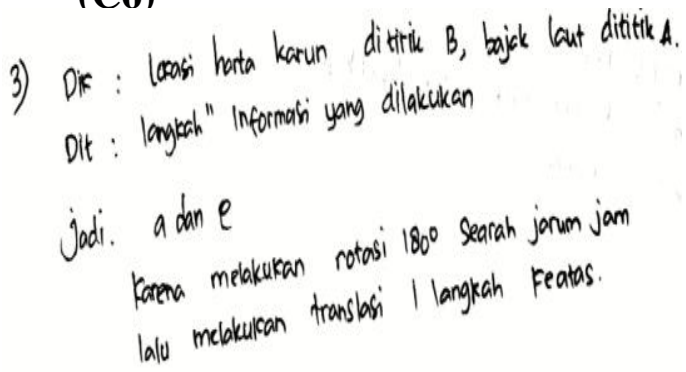

Gambar 6. Jawaban DAP dalam memecahkan soal level kognitif mencipta

Berdasarkan Gambar 5, dapat dijelaskan beberapa hal, yaitu: (1) Memahami masalah, pada tahap ini DAP memahami permasalahan pada level kognitif mencipta dan menjelaskan permasalahan tersebut dengan baik. DAP menuliskan informasi yang diberikan pada lembar jawaban, sehingga DAP memenuhi indikator memahami masalah; (2) Merencanakan penyelesaian, pada tahap ini DAP memahami rencana yang harus dilakukan dalam menyelesaikan permasalahan yang diberikan dan menjelaskan rencananya secara lisan. DAP menuliskan rencana yang akan dilakukan pada lembar soal, sehingga DAP memenuhi indikator merencanakan penyelesaian; (3) Melaksanakan penyelesaian, pada tahap ini DAP tidak mampu melaksanakan strategi penyelesaian yang dipilihnya, DAP tidak mampu merancang ide atau gagasannya dalam menjawab soal level kognitif mencipta, sehingga DAP belum memenuhi indikator melaksanakan penyelesaian; (4) Memeriksa kembali, pada tahap ini DAP tidak menemukan solusi dari masalah yang diberikan, sehingga DAP belum memenuhi indikator memeriksa kembali

Adapun cuplikan wawancara dengan siswa dengan kemampuan spasial sedang yaitu :

$R$ : Kamu paham gak dengan maksud soal no 1,2, dan 3 ?

$D A P$ : Iya paham pak

$R \quad$ : Bagaimana dengan maksud soal 1,2, dan 3 ?

DAP : Soal no 1, diminta hasil translasi dari tempat duduk pak, soal no 2 kita diminta untuk memilih pernyataan yang bener, kalo soal no 3 kita disuruh dapetin jalan dari $A$ ke $B$ supaya harta karunnya ketemu pak

$R \quad$ : Gimana cara nyelesainnya?

$D A P$ : Yang no 1, tinggal diliat perpindahan kanan, kiri, atas, dan bawahnya pak terus disesuain sama aturan disoal pak. Kalo no 2 itu tinggal milih aja, kalo no 3 milih transformasi yang dilakuin dari pilihan pak supaya harta karun ketemu.

$R$ : Kamu udh cek jawabannya, yakin gak?

DAP : No 1 sama 2 yakin pak, tapi no 3 saya bingung pak, belum nemuin idenya supaya harta karun ketemu.

\section{Siswa dengan Kemampuan Spasial Rendah}

Pada siswa dengan kemampuan spasial rendah yaitu RFB memperoleh skor 52,94 yang masuk dalam kategori skor kemampuan spasial rendah. Penjelasan dari setiap level kognitif adalah sebagai berikut. 
a. Soal Level Kognitif Menganalisis (C4)

$$
\begin{aligned}
& \text { 1.) Diketahui : Positiff }\left\{\begin{array} { l } 
{ \text { Depon } } \\
{ \text { koron } }
\end{array} \text { negatif } \left\{\begin{array}{l}
\text { Belakang } \\
\text { kiri }
\end{array}\right.\right. \\
& \text { Ditonya : Perpindchan steven, winda, Surya, Boy } \\
& \text { Steven berpindah } 3 \text { kekiri, } 3 \text { kebelakang } T\left(\begin{array}{c}
-3 \\
-3
\end{array}\right) \\
& \text { winda berpindah } 4 \text { ketiri I Kebelakang } \uparrow\left(\begin{array}{c}
-4 \\
-1
\end{array}\right) \\
& \text { Surya berpindah } 4 \text { kedepan, Iketiri } T\left(\begin{array}{c}
4 \\
-1
\end{array}\right) \\
& \text { Boy berpinctah } 3 \text { ketanan, } 3 \text { kedepan } T\left(\begin{array}{l}
3 \\
3
\end{array}\right)
\end{aligned}
$$

Gambar 7. Jawaban RFB dalam memecahkan soal level kognitif menganalisis

Gambar 7 menunjukkan tahapan pemecahan masalah yang dilakukan oleh RFB sebagai berikut, (1) Memahami masalah, pada tahap ini RFB mampu mengidentifikasi masalah yang disajikan dalam soal dengan benar, sehingga RFB memenuhi indikator memahami masalah; (2) Merencanakan penyelesaian, RFB mampu menghubungkan apa yang menjadi permasalahan dalam soal dan menjelaskan strategi yang harus dilakukan dalam menyelesaikan masalah tersebut, sehingga RFB memenuhi indikator merencanakan penyelesaian; (3) Melaksanakan penyelesaian, siswa RFB mampu melaksanakan strategi yang dipilihnya dengan baik dan benar; (4) Memeriksa kembali, siswa RFB melakukan proses pengecekan pada soal yang diberikan.

\section{b. Soal Level Kognitif Mengevaluasi (C5)}

2) c) Dik: Penyataan I: karena jarak senter didekatkan Packa bayongan Felinci
Penyataan II : Farena jarak senter dijauhkan
Pada bayangan Kelinci

Gambar 8. Jawaban RFB dalam memecahkan soal level kognitif mengevaluasi
Tahapan pemecahan masalah yang dilakukan oleh RFB sebagai berikut, (1) Memahami masalah, Pada tahap ini RFB mampu memahami permasalahan yang diberikan. RFB mampu menjelaskan kembali informasi yang diberikan, sehingga RFB memenuhi indikator memahami masalah; (2) Merencanakan Penyelesaian, Pada tahap ini siswa RFB belum mampu menghubungkan apa yang menjadi permasalahan dalam soal dan menjelaskan strategi yang harus dilakukan dalam menyelesaikan masalah tersebut, sehingga RFB belum memenuhi indikator merencanakan penyelesaian; (3) Melaksanakan penyelesaian, pada tahap ini RFB belum mampu melaksanakan strategi yang dipilihnya dengan baik, sehingga RFB belum memenuhi indikator melaksanakan penyelesaian; (4) Memeriksa kembali, pada tahap ini, siswa RFB belum memperoleh jawaban yang benar, sehingga RFB belum memenuhi indikator memeriksa kembali.

\section{c. Soal Level Kognitif Mencipta (C6)}

$$
\text { 3) d) } 90^{\circ}
$$

Gambar 9. Jawaban RFB dalam memecahkan soal level kognitif mencipta

Pada soal dengan level kognitif mencipta, siswa RFB tidak dapat menjawab soal dengan benar. Siswa RFB sama sekali tidak menuliskan langkah-langkah pemecahan masalah dan tidak bisa mengerjakan soal dengan level kognitif mencipta.

Berikut ini cuplikan wawancara dengan siswa dengan kemampuan spasial rendah yaitu :

$R \quad:$ Kamu paham gak dengan 
DOI: https://doi.org/10.24127/ajpm.v10i3.3874

maksud soal no 1,2, dan 3 ?

RFB : No 1 paham pak, no 2 sama 3 belum paham pak

$R \quad$ : Bagaimana dengan maksud soal 1?

$R F B$ : Soal no 1, membuat translasi dari perpindahan tempat duduk pak

$R \quad$ : Gimana cara nyelesainnya?

$R F B$ : Yang no 1, perpindahan tempat duduknya dihitung, kemudian disesuaikan dengan aturan yang positif dan negatifnya

$R$ : Kamu udh cek jawabannya, yakin gak?

$R F B$ : UdAh, no l yakin pak

Berdasarkan data hasil penelitian, terdapat perbedaan kemampuan pemecahan masalah siswa ditinjau dari kemampuan spasial. Perbedaan kemampuan tersebut dapat dilihat pada Tabel 3.

Tabel 3. Pemecahan Masalah dalam HOTS ditinjau dari Kemampuan Spasial

\begin{tabular}{ccccccccccccc}
\hline \multirow{2}{*}{$\begin{array}{c}\text { Kemampuan } \\
\text { Spasial }\end{array}$} & \multicolumn{1}{c}{ Menganalisis (C4) } & \multicolumn{1}{c}{ Mengevaluasi (C5) } & \multicolumn{4}{c}{ Mencipta (C6) } \\
\cline { 2 - 11 } & $\mathbf{M}_{\mathbf{1}}$ & $\mathbf{M}_{\mathbf{2}}$ & $\mathbf{M}_{\mathbf{3}}$ & $\mathbf{M}_{\mathbf{4}}$ & $\mathbf{M}_{\mathbf{1}}$ & $\mathbf{M}_{\mathbf{2}}$ & $\mathbf{M}_{\mathbf{3}}$ & $\mathbf{M}_{\mathbf{4}}$ & $\mathbf{M}_{\mathbf{1}}$ & $\mathbf{M}_{\mathbf{2}}$ & $\mathbf{M}_{\mathbf{3}}$ & $\mathbf{M}_{4}$ \\
\hline Tinggi ( UVK) & $\checkmark$ & $\checkmark$ & $\checkmark$ & $\checkmark$ & $\checkmark$ & $\checkmark$ & $\checkmark$ & $\checkmark$ & $\checkmark$ & $\checkmark$ & $\checkmark$ & $\checkmark$ \\
Sedang ( DAP) & $\checkmark$ & $\checkmark$ & $\checkmark$ & $\checkmark$ & $\checkmark$ & $\checkmark$ & $\checkmark$ & $\checkmark$ & $\checkmark$ & $\checkmark$ & & \\
Rendah (RFB ) & $\checkmark$ & $\checkmark$ & $\checkmark$ & $\checkmark$ & $\checkmark$ & & & & & & \\
\hline
\end{tabular}

Keterangan :

$\mathrm{M}_{1}=$ Tahap Memahami Masalah,

$\mathbf{M}_{3}=$ Tahap Melaksanakan Penyelesaian

Berdasarkan data pada Tabel 3 menunjukan bahwa siswa dengan kemampuan spasial tinggi (UVK) mampu menyelesaikan soal berbasis HOTS pada level kognitif menganalisis, mengevaluasi, dan mencipta, siswa dengan kemampuan spasial sedang (DAP) mampu menyelesaikan soal berbasis HOTS pada level kognitif menganalisis, mengevaluasi, dan untuk soal dengan level kognitif mencipta siswa hanya mampu memahami masalah dan merencanakan strategi, namun tidak dapat melaksanakan penyelesaian serta meninjau kembali, siswa dengan kemampuan spasial rendah (RFB) hanya mampu menyelesaikan soal dengan level kognitif menganalisis, untuk soal mengevaluasi hanya mampu memahami masalah, sedangkan untuk soal dengan level kognitif mencipta siswa RFB belum mampu menyelesaikan soal. Hasil tersebut menunjukan bahwa
$\mathbf{M}_{2}=$ Tahap Merencanakan Penyelesaian

$\mathbf{M}_{4}=$ Tahap Memeriksa Kembali

kemampuan spasial siswa berkemampuan tinggi lebih baik daripada siswa berkemampuan sedang dan rendah dalam menyelesaikan masalah geometri transformasi. Begitu pula, kemampuan spasial siswa berkemampuan sedang lebih baik daripada siswa berkemampuan rendah dalam menyelesaikan masalah geometri transformasi berbasis HOTS, hal ini sejalan dengan penelitian sebelumnya oleh Evi febriana yang menyatakan bahwa terdapat perbedaan kemampuan siswa dalam menyelsaikan masalah geometri dimensi tinggi jika dilihat dari kemampuan spasial (Febriana, 2015). Dalam kemampuan memanipulasi secara mental suatu objek, siswa berkemampuan tinggi menggunakan strategi yang lebih variatif, yaitu membayangkan mengubah secara mental suatu objek ke dalam bentuk berbeda, dengan melihat kesamaan bentuk dan melihat kemungkinan di 
mana ia mencoba melihat perubahan posisi yang mungkin terjadi. Sementara itu, siswa berkemampuan sedang dan rendah membayangkan perubahan suatu objek ke dalam bentuk berbeda dan dengan melihat kesamaan bentuk guna menyelesaikan masalah yang diberikan. Ini menunjukkan bahwa siswa berkemampuan tinggi dalam menyelesaikan masalah tranformasi memiliki kemampuan memanipulasi secara mental suatu objek yang lebih baik dibanding siswa berkemampuan sedang dan rendah yang bisa dilihat berdasarkan hasil jawaban dan wawancara siswa. Hasil penelitian yang sama juga relevan dengan penelitian oleh Ary Hidayah Putri yang menyatakan bahwa adanya pengaruh positif nilai tes kemampuan spasial terhadap tes kemampuan geometri (Putri, 2017) ini menunjukan bahwa terdapat pengaruh antara kemampuan spasial terhadap kemampuan geometri pada peserta didik SMP.

Kebaharuan penelitian ini berdasarkan penelitian terdahulu adalah penelitian ini menganalisis kemampuan pemecahan masalah siswa dalam menyelesaikan soal geometri transformasi ditinjau dari kemampuan spasial. Hasil ini bertolak belakang dengan hasil penelitian oleh Arifin dan Novisita Ratu yang menyatakan bahwa subjek berkemampuan tinggi mampu mencapai tahap menganalisis dan mengevaluasi tetapi tidak mampu mencapai tahap mencipta. Subjek berkemampuan sedang hanya mampu mencapai pada tahap menganalisis dan tidak mampu mencapai tahap mengevaluasi dan mencipta. Subjek berkemampuan rendah tidak mampu mencapai tahap menganalisis, mengevaluasi, dan mencipta (Arifin \& Ratu, 2018)

Berdasarkan hasil penelitian diperoleh bahwa siswa dengan kemampuan spasial tinggi memiliki kemampuan yang lebih baik dalam pemecahan masalah geometri transformasi berbasis HOTS. Hasil penelitian ini dapat dijadikan bahan pertimbangan bagi guru dan peneliti lain untuk dapat mengembangkan kemampuan spasial siswa karena memberikan pengaruh positif terhadap proses pemecahan masalah khususnya dalam bidang geometri.

\section{KESIMPULAN DAN SARAN}

Berdasarkan hasil penelitian, siswa dengan kemampuan spasial tinggi mampu melalui tahapan pemecahan masalah pada soal geometri transformasi dengan level kognitif menganalisis, mengevaluasi, dan mencipta. Siswa dengan kemampuan sedang mampu melalui tahapan pemecahan masalah dengan level kognitif menganalisis dan mengevaluasi, Sedangkan untuk level kognitif mencipta, siswa ini hanya mampu memahami masalah dan merencanakan penyelesaian. Siswa ini tidak mampu menjalankan penyelesaian dengan baik dan tidak menemukan gagasan untuk pemecahan masalah yang diberikan. Siswa dengan kemampuan rendah hanya mampu melalui tahapan pemecahan masalah dengan level kognitif menganalisis, sedangkan soal dengan level kognitif mengevaluasi dan mencipta, siswa ini tidak mampu menyelesaikan soal dengan baik. Hal ini menunjukkan bahwa siswa dengan kemampuan spasial tinggi memiliki kemampuan lebih baik dalam mengerjakan soal geometri transformasi berbasis high order thinking dibandingkan siswa dengan kemampuan spasial sedang dan rendah.

Berdasarkan hasil penelitian yang telah dilakukan, adapun saran untuk penelitian selanjutnya yaitu agar dapat 
menganalisis tentang kemampuan lain dalam pembelajaran matematika dengan menggunakan soal berbasis HOT ditinjau dari berbagai aspek. Hal itu dilakukan agar semakin memperkaya keilmuan yang akan diperoleh.

\section{DAFTAR PUSTAKA}

Agoestanto, Arief, \& Safitri, S. N. (2013). Keefektifan Pembelajaran Matematika Mengacu Pada Missouri Mathematics Project Terhadap Kemampuan Pemecahan Masalah. Prosiding Seminar Nasional Matematika VII UNNES, 71-77.

Arifin, \& Ratu, N. (2018). Profil Higher Order Thingking Skill Siswa Dalam Menyelesaikan Masalah Bangun Datar Segi Empat. Maju, 5(2), 5263.

Azizah, F. R. (2015). Analisis Kemampuan Pemecahan Masalah Matematika Berdasarkan Taksonomi SOLO pada Sub Pokok Bahasan Balok Siswa Kelas VIII-H SMP. 1-241.

Capriora, D. (2015). Problem SolvingPurpose and Means of Learning Mathematics in School. ProcediaSocial and Behavioral Sciences, 1(9), 1859--1864.

Fajri, H. N., Johar, R., \& Ikhsan, M. (2016). Peningkatan Kemampuan Spasial dan Self-Efficacy Siswa Melalui Model Discovery Learning Berbasis Multimedia. Jurnal Tadris Matematika, 9(2), 180-196.

Febriana, E. (2015). Profil Kemampuan Spasial Siswa Menengah Pertama (SMP) Dalam Menyelesaikan Masalah Geometri Dimensi Tiga Ditinjau Dari Kemampuan Matematika. Jurnal Elemen, 1(1), 13-23.

Gunur, B., Alberta, \& Apolonia. (2018). Hubungan Antara Kemampuan Numerik dengan Kemampuan Pemecahan Masalah Matematis
Siswa di Pedesaan. MaPan : Jurnal Matematika Dan Pembelajaran, 6(2), 148-160.

Gurun, J., Kubang, A., \& Agam, P. (2018). Profil Kemampuan Spasial Mahasiswa Camper Dalam Merekonstruksi Irisan Prisma Ditinjau Dari Perbedaan Gender. MaPan: Jurnal Matematika Dan Pembelajaran, 6(1), 31-39.

Hodiyanto, H. (2018). Kemampuan spasial sebagai prediktor terhadap prestasi belajar geometri mahasiswa. Jurnal Mercumatika: Jurnal Penelitian Matematika Dan Pendidikan Matematika, 2(2), 5965.

https://doi.org/10.26486/jm.v2i2.36 4

Imamah, F. U., \& Toheri. (2014). Pengaruh Penggunaan Kombinasi Metode Pembelajaran Discovery Learning Dan Brain Storming Terhadap Kemampuan Pemecahan Masalah Pada Pokok Bahasan Himpunan. EduMa, 3(1), 120-137.

Komala, E. (2012). Pembelajaran dengan Pendekatan Diskursif untuk Meningkatkan Kemampuan Pemecahan Masalah Matematis dan Self-Concept Siswa Sekolah Menengah Pertama. Tesis Pada SPS UPI. Tidak Dipublikasikan.

Kusuma, A. P. (2017). Implementasi Model Pembelajaran Student Teams Achievement Division dan Team Assisted Individualization ditinjau dari Kemampuan Spasial Siswa. Al-Jabar: Jurnal Pendidikan Matematika, 8(2), 135-144.

Kusumawati, S. W. (2014). Penerapan Model Pembelajaran SAVI Untuk Meningkatkan Keterampilan Pemecahan Masalah di Sekolah Dasar. JPGSD, 2(2), 1-10.

Lailly, N. R., \& Wisudawati, A. W. (2015). Analisis Soal Tipe Higher Order Thingking Skill ( HOTS) Dalam Soal UN Kimia SMA Rayon B Tahun 2012/2013. Kaunia, XI(1), 
DOI: https://doi.org/10.24127/ajpm.v10i3.3874

27-39.

Mahmudiati, R., \& Alawiyah, L. (2018). Peningkatan Kemampuan Visual Spasial Siswa Melalui Penggunaan Butir Soal Hots. Seminar Nasional Hasil Penelitian Dan Pengabdian Masyarakat, September.

Mita, D. S., Tambunan, L. R., \& Izzati, N. (2019). Analisis Kemampuan Pemecahan Masalah Peserta Didik Dalam Menyelesaikan Soal PISA. Lentera Sriwijaya: Jurnal Ilmiah Pendidikan Matematika, 1(2), 2533.

Negara, H. R., Atmojo, T., \& Sujadi, I. (2014). Eksperimentsi Model Pembelajaran Kooperatif Tipe Jigsaw dengan Pendekatan CTL terhadap Prestasi belajar dan Aspek Afektif Siswa pada Materi bangun Ruang Sisi Datar DItinjau dari Kemampuan Spasial. JMME, 4(2), 47-63.

Ngaeni, E. N., \& Saefudin, A. A. (2017). Menciptakan Pembelajaran Matematika yang Efektif Dalam Pemecahan Masalah Matematika Dengan Model pembelajaran Problem Posing. Jurnal Aksioma, 6(2), 264-274.

Nugroho, A. A., Putra, R. W. Y., Putra, F. G., \& Syazali, M. (2017). Pengembangan Blog sebagai Media Pembelajaran Matematika. AlJabar: Jurnal Pendidikan Matematika, 8(2), 197-204.

Nurhayati, E., Mulyana, T., \& Martadiputra, B. A. P. (2016). Penerapan scaffolding untuk pencapaian kemampuan pemecahan masalah matematis. Jurnal Penelitian Pendidikan Dan Pengajaran Matematika, 2(2), 107112.

Putra, M., \& Novita, R. (2014). Pemecahan Masalah Matematika Tipe PISA Pada Siswa Sekolah Menengah Dengan Konten Hubungan dan Perubahan. Jurnal
MAJU ( Jurnal Pendidikan Matematika), 1(1), 37-46.

Putri, A. H. (2017). Pengaruh Kemampuan Spasial Terhadap Kemampuan Geometri Pada Peserta Didik Kelas VIII SMP Swasta Di Kecamatan Kebomas Gresik. Didaktika, 23(2), 114-121.

Ramadhani, R. (2017). Kemampuan Pemecahan Masalah Matematika Siswa SMA Melalui Guided Discovery Learning Berbantuan Autograph. JPPM, 10(2), 72-81.

Rikanah, D., \& Winarso, W. (2016). Penguasaan Konsep Lingkaran Terhadap Kemampuan Spasial Matematika Siswa Pokok Bahasan Bangun Ruang Sisi Lengkung Kelas VIII SMP Negeri 1 Kota Cirebon. Jurnal Pendidikan Matematika, 10(1), 15-27.

Simanjuntak, E., Hia, Y., \& Manurung, N. (2019). Analisis Kemampuan Berpikir Kreatif Dalam Pemecahan Masalah Ditinjau Dari Gender. School Education Journal, 9(3), 213-220.

Suroyya, D. N., \& Rochmad. (2015). Studi Komparasi Pembelajaran Novick Dan Group Investigation Terhadap Kemampuan Spasial Siswa Kelas VIII Materi Geometri. Unnes Journal of Mathematics Education, 4(1), 96-102.

Syahputra, E. (2013). Peningkatan Kemampuan Spasial Siswa Melalui Penerapan Pembelajaran Matematika Realistik. Cakrawala Pendidikan, 32(3), 353-364.

Yurniati, \& Wahyuningrum, E. (2015). Pembelajaran Berbasis ICARE Dalam Tutorial Online Untuk Meningkatkan Kemampuan Pemecahan Masalah Matematis Mahasiswa UT. Infinity, 4(2), 182189. 